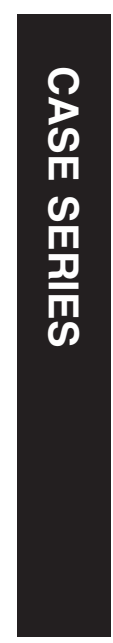

\title{
A co-occurrence of familial isolated cherry red spot and multiple lens opacities
}

${ }^{1}$ Department of

Ophthalmology, School of Medicine, Yuzuncu Yil

University, Van, Turkey

${ }^{2}$ Department of Ophthalmology, School of Medicine, Istanbul Medeniyet University, Istanbul, Turkey

${ }^{3}$ Department of Pediatrics, Division of Pediatric Endocrinology, School of Medicine, Yuzuncu Yil University, Van, Turkey

Correspondence: R Karadag, Department of Ophthalmology, Faculty of Medicine, Medeniyet University, Istanbul, Turkey. Tel: +90 2162803333 ; Fax: +90 2166022800 . E-mail: drrkaradag@ yahoo.com

Received: 8 May 2013 Accepted in revised form: 2 November 2013 Published online: 20 December 2013

\begin{abstract}
Purpose To present a co-occurrence of familial isolated cherry red spot (CRS) and multiple lens opacities in all siblings from the same family without any other systemic or ocular diseases.

Methods Four siblings from the same family had bilateral punctate lens opacities and bilateral CRS at the macula.

Results The oldest one had left eye exotropia and amblyopia, otherwise the other siblings had no additional ocular findings. Systemic investigation, physical examination, and laboratory tests were within normal limits.

Conclusion Bilateral isolated CRS along with punctate lens opacities were seen in all siblings from the same family without any systemic and ocular diseases.

Eye (2014) 28, 344-347; doi:10.1038/eye.2013.271; published online 20 December 2013
\end{abstract}

Keywords: cataract; cherry red spot; familial; isolated; lens opacities

\section{Introduction}

A cherry red spot (CRS) is an important fundus finding. It includes posterior pole retinal thickening, nontransparency, and color changes. ${ }^{1}$ In some storage disorders, its related materials can accumulate in the ganglion cell layers causing retinal swelling and loss of retinal transparency. Owing to the absence of ganglion cell layers in the fovea and the transparent appearance of retina, choroidal structures can be seen in the fovea. ${ }^{2}$ CRS can be seen in central retinal artery (CRA) occlusion. Retinal ischemia can cause pale appearance in perimacular structure, but the fovea keeps its normal appearance. ${ }^{1}$ Dapson and methanol toxicity can cause CRS as well..$^{3,4}$ In addition, co-occurrence of cataract and CRS was reported in some diseases. ${ }^{5}$ However, isolated CRS or co-occurrence of CRS and cataract without any underlying diseases has not reported before. We report the cases due to the presence of their co-occurrence without any systemic or ocular disease.

\section{Case reports}

Case 1

A 16-year-old male presented with poor visual acuity and deviation in his left eye. He had left eye deviation as an infant and he had previous strabismus surgery 10 years ago. On ophthalmological examination, the bestcorrected visual acuity (BCVA) was 20/20 on the right eye and 20/400 on the left eye (with snellen chart). Forty-prism diopter of left eye exotropia was detected. Intraocular pressure (IOP) was $10 \mathrm{~mm} \mathrm{Hg}$ bilaterally. Anterior segment exam showed bilateral punctate multiple lens opacities (PMLOs) (Figure 1a). Bilateral CRS appearance was present on the fundus examination (Figure 1b). All family members were examined due to presence of cross-cousin marriage of the parent. On family examination, his mother and father had normal ophthalmologic examination.

Case 2

A 14-year-old male sibling was admitted to the control eye examination. On ophthalmological examination, the BCVA was 20/20 bilaterally (with snellen chart) IOP was $12 \mathrm{~mm} \mathrm{Hg}$ bilaterally. On anterior segment examination, bilateral PMLO were detected (Figure 1c). On fundus examination, bilateral CRS appearance was present (Figure 1d). 


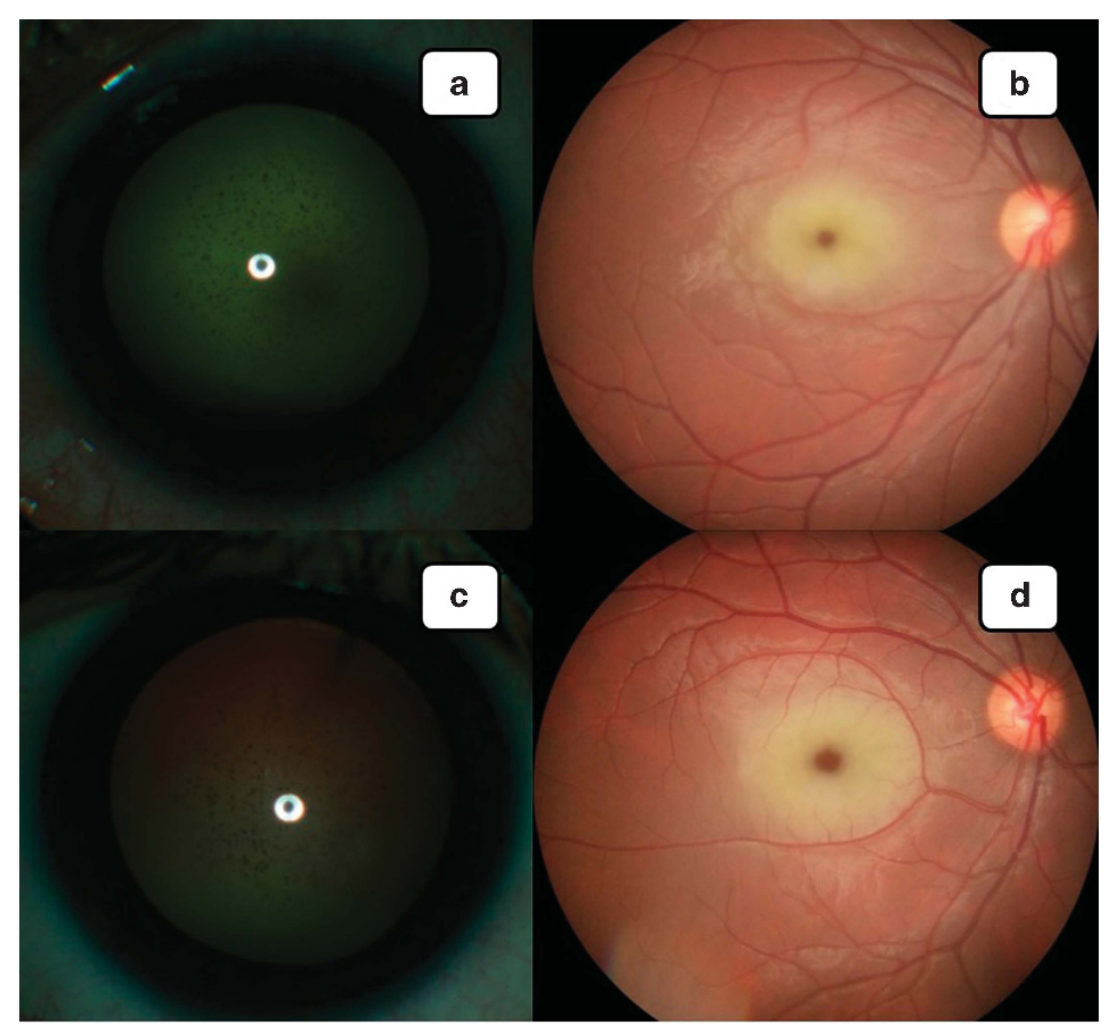

Figure 1 A 16-year-old patient presenting multiple lens opacities (a) and CRS appearance (b) in the right eye. Multiple lens opacities (c) and CRS appearance (d) in right eye of 14-year-old patient.

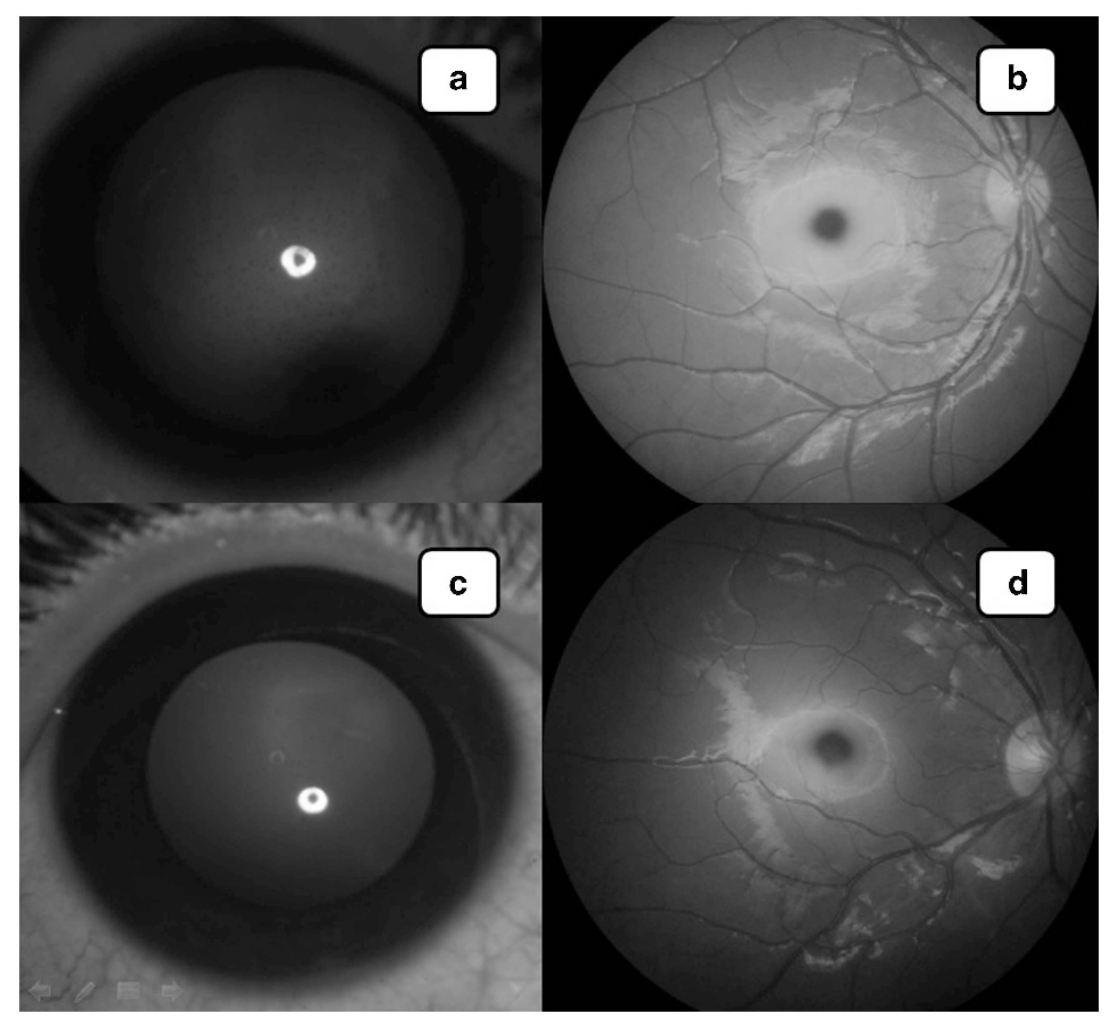

Figure 2 Multiple lens opacities (a) and CRS appearance (b) in right eye of 11-year-old patient. Multiple lens opacities (c) and CRS appearance (d) in right eye of 4-year-old patient. 


\section{Case 3}

A 11-year-old male sibling had normal visual acuity and normal IOP. Anterior segment exam demonstrated bilateral PMLO (Figure 2a). Bilateral CRS appearance was present on the fundus examination (Figure $2 b$ ).

\section{Case 4}

A 4-year-old female sibling had normal visual acuity and normal IOP. On anterior segment examination, bilateral PMLO were detected (Figure 2c). On fundus examination, bilateral CRS appearance was present (Figure 2d).

Table 1 The disorders that have role in cherry red spot etiopathogenesis and performed tests

\begin{tabular}{|c|c|c|c|}
\hline Disorders & Enzyme deficiency & Abnormal findings & $\begin{array}{l}\text { Our patient's value/(normal } \\
\text { range) }\end{array}$ \\
\hline \multicolumn{4}{|l|}{ Metabolic, storage disorders } \\
\hline Sialidosis (mucolipidoses) & $\begin{array}{l}\text { Alpha-N-acytylneuraminidase (disorder of } \\
\text { lysosomal enzyme phosphorylation) }\end{array}$ & Sialic acid excretion & $\begin{array}{l}\text { Urinary sialic acid excretion } \\
\text { was normal }\end{array}$ \\
\hline $\begin{array}{l}\text { Niemann-Pick type A } \\
\text { (lipidoses) }\end{array}$ & $\begin{array}{l}\text { Sphingomyelinase (impaired sphingomyelin } \\
\text { metabolism) }\end{array}$ & $\begin{array}{l}\text { Sphingomyelinase enzyme } \\
\text { activity } \\
\text { Decreased } \\
\text { Hematocrit } \\
\text { Hemoglobin } \\
\text { Platelet count } \\
\text { Red blood count } \\
\text { White blood cell count/ } \\
\text { leukocytes }\end{array}$ & $\begin{array}{l}1.3 \mu \mathrm{mol} / \mathrm{g} / \mathrm{h}(\mathrm{N}: 1-10) \\
\text { Normal }\end{array}$ \\
\hline Farber lipogranulomatosis & Acid ceramidase (error in ceramide metabolism) & $\begin{array}{l}\text { X-ray/chest abnormal } \\
\text { X-ray/wrist abnormal }\end{array}$ & $\begin{array}{l}\text { Normal } \\
\text { Normal }\end{array}$ \\
\hline GM 2 type I (Tay-Sachs) & Hexosaminidase B-alpha subunit & $\begin{array}{l}\text { Plasma B-hexosaminidase A } \\
\text { enzyme activity } \\
\text { Decreased } \\
\text { Urine hexosaminidase } \\
\text { Increased } \\
\text { Aldolase (serum) }\end{array}$ & $\begin{array}{l}116 \mu \mathrm{mol} / 1 / \mathrm{h}(\mathrm{N}: 50-250) \\
\text { Normal } \\
\text { Normal }\end{array}$ \\
\hline GM 2 type II (Sandhoff) & Hexosaminidase A and B-beta subunit & $\begin{array}{l}\text { Plasma B-hexosaminidase A and } \\
\text { B enzyme activity } \\
\text { Decreased } \\
\text { Urine hexosaminidase }\end{array}$ & $\begin{array}{l}1469 \mu \mathrm{mol} / 1 / \mathrm{h}(N: 600-3500) \\
\text { Normal }\end{array}$ \\
\hline $\begin{array}{l}\text { Hurler's } \\
\text { mucopolysaccharidoses }\end{array}$ & Alpha-L-iduronidase & $\begin{array}{l}\text { Increased } \\
\text { Urine } \\
\text { Dermatan sulfate } \\
\text { Heparan sulfate } \\
\text { mucopolysaccharides }\end{array}$ & Normal \\
\hline $\begin{array}{l}\text { Cerebral Gaucher's of } \\
\text { infants (acute) }\end{array}$ & Acid beta-glucosidase & B-glucosidase & $2.1 \mu \mathrm{mol} / \mathrm{g} / \mathrm{h}(N: 1.0-5.0)$ \\
\hline $\begin{array}{l}\text { Beta-glucuronidase deficiency } \\
\text { syndrome (MPS VII) }\end{array}$ & Beta-glucuronidase & $\begin{array}{l}\text { Increased } \\
\text { Urine } \\
\text { Dermatan sulfate } \\
\text { Keratan sulfate } \\
\text { Mucopolysaccharides }\end{array}$ & Normal \\
\hline $\begin{array}{l}\text { Gangliosidosis, generalized } \\
\text { (GM1): }\end{array}$ & Galactocerebroside B-galactosidase & $\begin{array}{l}\text { B-galactosidase enzyme activity } \\
\text { Increased } \\
\text { Urine keratan sulfate }\end{array}$ & $\begin{array}{l}114 \mu \mathrm{mol} / \mathrm{g} / \mathrm{h}(\mathrm{N}: 100-400) \\
\text { Normal }\end{array}$ \\
\hline $\begin{array}{l}\text { Juvenile ceroid lipofuscinosis / } \\
\text { Batten-M }\end{array}$ & Gene locus chromosome 16 & $\begin{array}{l}\text { Increased } \\
\text { Urine dolichol }\end{array}$ & Normal \\
\hline Goldberg syndrome & Neuraminidase/Beta-galactosidase defects & $\begin{array}{l}\text { Increased } \\
\text { Urine glycoproteins }\end{array}$ & Normal \\
\hline \multicolumn{4}{|c|}{ Usage, degenerative, necrosis, age related disorders } \\
\hline $\begin{array}{l}\text { Metachromatic } \\
\text { leukodystrophy (lipidoses) }\end{array}$ & Arylsulfatase A (defect in metabolism of myeline) & $\begin{array}{l}\text { Arylsulphatase A enzyme } \\
\text { activity } \\
\text { Decreased } \\
\text { Lactic acid/lactate (Serum) } \\
\text { Increased } \\
\text { Aspartamine aminotransferase } \\
\text { (SGOT, AST) }\end{array}$ & $\begin{array}{l}61 \mu \mathrm{mol} / 1 / \mathrm{h}(\mathrm{N}: 50-250) \\
\text { Normal } \\
\text { Normal }\end{array}$ \\
\hline \multicolumn{4}{|l|}{ Hereditary, familial, genetic disorders } \\
\hline Hallervorden-Spatz disease & & $\begin{array}{l}\text { Mental retardation progressive/ } \\
\text { myoclonus epilepsy }\end{array}$ & $\begin{array}{l}\text { Systemic examination was } \\
\text { normal }\end{array}$ \\
\hline Leukodystrophy, Krabbe & Galactocerebroside B-galactosidase & Urinary sialic acid excretion & $\begin{array}{l}\text { Urinary sialic acid excretion } \\
\text { was normal }\end{array}$ \\
\hline
\end{tabular}


All siblings were referred to pediatric endocrinology and metabolic diseases. After their detailed examination, no mental or systemic diseases were detected. A past medical history of the siblings was negative for trauma history, neurological disease, intellectual impairment, drug toxicity, muscle disorders, and cardiovascular diseases. Further laboratory tests for systemic and storage diseases were unremarkable (Table 1). The siblings were diagnosed with isolated CRS and scheduled for periodic follow ups.

\section{Discussion}

CRS at the macula is commonly seen in hereditary storage diseases, CRA occlusion due to several causes, and several drug toxicities. ${ }^{2,6}$ Hereditary metabolic storage disorders presenting with CRS include Tay-Sachs disease, gangliosidosis, Sandhoff disease, Farber disease, sialidosis, Niemann-Pick disease, metachromatic leukodystrophy, and galactosialidosis. ${ }^{1,6-8}$ In our cases, all detailed examinations and laboratory analysis were negative for metabolic diseases, intellectual impairment, psychomotor retardation, and musculoskeletal diseases. Therefore, we could not detect any hereditary metabolic diseases.

CRS at the macular can be seen in CRA occlusions. ${ }^{1,9-11}$ In our cases, only the oldest sibling had amblyopia and its related eye deviation. The ophthalmological findings (except bilateral PMLO and CRS appearance) of the other siblings were within normal limits. None of them had history of sudden visual loss, trauma, or ocular surgery (except strabismus surgery of the oldest sibling).

Toxicity to drugs and gases can cause CRS at the macula, and these include dapson, methanol, quinine, and carbon monoxide. .,3,4 $^{2}$

When the literature is observed in the etiopathogenesis of CRS, hereditary metabolic storage disorders, 1,6-8 CRA occlusion, ${ }^{1,9-11}$ drugs and gases toxicities ${ }^{1,3,4}$ have a role. We performed required laboratory tests and systemic examination for storage disorders and found out them in normal limits in our patients. We performed detailed ocular examination that includes visual acuity, IOP, slit lamp, and fundus examination and fundus fluorescein angiography for CRA. We found out all of them in normal limits except on sibling who has exotropia and amblyopia. We did not have any findings about drugs and gas toxicity. For this reason, we evaluated CRS in our patients as isolated.

Isolated CRS at the macula has been infrequently reported in the literature. ${ }^{12}$ However, we have not encountered a case with co-occurrence of CRS at the macula and PMLO without any accompanying ocular and metabolic diseases in the literature.
In conclusion, this case is unique due to co-occurrence of CRS at the macula and PMLO without any accompanying ocular or metabolic diseases in all four siblings.

\section{Summary}

\section{What was known before}

- Cherry red spot (CRS) at the macula is commonly seen in hereditary storage diseases, central retinal artery occlusion due to several causes, and several drug toxicities.

\section{What this study adds}

- This case is unique due to co-occurrence of CRS and multiple punctate lens opacities without any accompanying ocular or metabolic diseases in all four siblings.

\section{Conflict of interest}

The authors declare no conflict of interest.

\section{References}

1 Suvarna JC, Hajela SA. Cherry-red spot. J Postgrad Med. 2008; 54: 54-57.

2 Johnston MV. Neurodegenerative disorders of childhood; Sphingolipidoses. In: Behrman RE, Kliegman RM, Jenson HB (eds) Nelson's textbook of Pediatrics. 17th ed. WB Saunders: Philadelphia, 2004, pp 2029-2035.

3 Abhayambika K, Chacko A, Mahadevan K, Najeeb OM. Peripheral neuropathy and haemolytic anaemia with cherry red spot on macula in dapsone poisoning. J Assoc Physicians India 1990; 38: 564-565.

4 McKellar MJ, Hidajat RR, Elder MJ. Acute ocular methanol toxicity: clinical and electrophysiological features. Aust $\mathrm{N} \mathrm{Z}$ J Ophthalmol 1997; 25: 225-230.

5 Nahata MC, Sethi PK, Chhabra ML, Khandekar JD, Dixit VP, Mukerji DP. Juvenile amaurotic family idiocy with cherry-red spot and cataract. Indian J Ophthalmol 1973; 21: 40-42.

6 Arisoy AE, Ozden S, Ciliv G, Ozalp I. Tay-Sachs disease: a case report. Turk J Pediatr 1995; 37: 51-56.

7 Caksen H, Tuncer O, Kirimi E, Fryns JP, Uner A, Unal O et al. Report of two Turkish infants with Norman-Roberts syndrome. Genet Couns 2004; 15: 9-17.

8 Usui T, Takagi M, Abe H, Iwata K, Tsuji S, Miyatake T. Adult-form galactosialidosis: ocular findings in three cases. Ophthalmologica 1991; 203: 176-179.

9 Varma DD, Cugati S, Lee AW, Chen CS. A review of central retinal artery occlusion: clinical presentation and management. Eye 2013; 27(6): 688-697.

10 Al-Abdulla NA, Haddock TA, Kerrison JB, Goldberg MF. Sickle cell disease presenting with extensive peri-macular arteriolar occlusions in a nine-year-old boy. Am J Ophthalmol 2001; 131: 275-276.

11 Ghose S, Subhabrata P. Bilateral central retinal arterial obstruction following head trauma: a very rare case report. Indian J Ophthalmol 2011; 59: 66-68.

12 Hartwig H, Kolling G, Best W. [Cherry red spot without secure evidence of sphingolipidosis (author's transl)]. Klin Monbl Augenheilkd 1978; 173: 716-719. 